\title{
Association of apolipoprotein E polymorphism in late-onset Alzheimer's disease and vascular dementia in Brazilians
}

\footnotetext{
D.R.S. Souza ${ }^{1}$,

M.R. De Godoy²,

J. Hotta ${ }^{3}$, E.H. Tajara ${ }^{4}$,

A.C. Brandão ${ }^{1}$,

S. Pinheiro Júnior ${ }^{1}$,

W.A. Tognola ${ }^{2}$ and

J.E. Dos Santos ${ }^{3}$
}

\author{
Departamentos de ${ }^{1}$ Biologia Molecular, and ${ }^{2}$ Ciências Neurológicas, \\ Faculdade de Medicina de São José do Rio Preto, São José do Rio Preto, SP, Brasil \\ ${ }^{3}$ Departamento de Clínica Médica, Faculdade de Medicina de Ribeirão Preto, \\ Universidade de São Paulo, Ribeirão Preto, SP, Brasil \\ ${ }^{4}$ Departamento de Biologia, Universidade Estadual Paulista Júlio de Mesquita Filho, \\ São José do Rio Preto, SP, Brasil
}

\section{Correspondence}

D.R.S. Souza

Departamento de Biologia Molecular FAMERP

Av. Brigadeiro Faria Lima, 5416 15090-000 São José do Rio Preto, SP Brasil

Fax: +55-17-227-5733

E-mail: doroteia@famerp.br

Research supported by FAPESP and CNPq.

Received July 3, 2002 Accepted February 28, 2003 ....................

\section{Abstract}

The genetic basis for dementias is complex. A common polymorphism in the apolipoprotein $\mathrm{E}(A P O E)$ gene is considered to be the major risk factor in families with sporadic and late-onset Alzheimer's disease as well as in the general population. The distribution of alleles and genotypes of the $A P O E$ gene in late-onset Alzheimer's disease $(\mathrm{N}=$ $68)$, other late-life dementias $(\mathrm{N}=39)$, and in cognitively normal controls $(\mathrm{N}=58)$ was determined, as also was the risk for Alzheimer's disease associated with the $\varepsilon 4$ allele. Peripheral blood samples were obtained from a total of 165 individuals living in Brazil aged 65-82 years. Genomic DNA was amplified by the polymerase chain reaction and the products were digested with $H$ haI restriction enzyme. APOE $\varepsilon 2$ frequency was considerably lower in the Alzheimer's disease group $(1 \%)$, and the $\varepsilon 3$ allele and $\varepsilon 3 / \varepsilon 3$ genotype frequencies were higher in the controls ( 84 and $72 \%$, respectively) as were the $\varepsilon 4$ allele and $\varepsilon 3 / \varepsilon 4$ genotype frequencies in Alzheimer's disease (25 and 41\%, respectively). The higher frequency of the $\varepsilon 4$ allele in Alzheimer's disease confirmed its role as a risk factor, while $\varepsilon 2$ provided a weak protection against development of the disease. However, in view of the unexpectedly low frequency of the $\varepsilon 4$ allele, additional analyses in a more varied Brazilian sample are needed to clarify the real contribution of apolipoprotein E to the development of Alzheimer's disease in this population.
In North America and Europe the most common dementia that affects the elderly is Alzheimer's disease (AD), corresponding to 55.6 to $72 \%$ of all dementia cases $(1,2)$. In a community-dwelling Brazilian population the
Key words

- Alzheimer's disease

- Vascular dementia

- Dementia

- Apolipoprotein E

- Aging

- Genetic polymorphisms 
loid precursor protein (APP, chromosome 21) and presenilin 1 and 2 genes (chromosomes 14 and 1, respectively). Considering the development of sporadic and late-onset $\mathrm{AD}$ (LOAD), a common polymorphism in the apolipoprotein $\mathrm{E}(A P O E)$ gene (chromosome 19) is the major risk factor in families with the disease, as well as in the general population (4). More recently, a new LOAD locus on chromosome 10 independent of the $A P O E$ genotype was discovered (5).

There are three common APOE alleles ( $\varepsilon 2, \varepsilon 3$ and $\varepsilon 4)$, accounting for more than $99 \%$ of the isoforms of the product of apo $\mathrm{E}$. The $\varepsilon 3$ allele is the most frequent, representing 74 to $86 \%$ of all alleles in European and American Caucasian populations. The $\varepsilon 4$ allele frequency is approximately 7 to $16 \%$ and the $\varepsilon 2$ allele frequency is 6.3 to $12 \%$ (610). Of these three, $\varepsilon 4$ is recognized as a risk factor for LOAD, whereas the $\varepsilon 2$ and $\varepsilon 3$ alleles appear to enhance tolerance to the brain degenerative process, extending the survival of affected neurons. The effect of the $A P O E \varepsilon 4$ allele has been associated with the pattern of regional brain atrophy in $\mathrm{AD}$ (11). In addition, the combination of low head circumference and $\varepsilon 4$ predicts earlyonset AD (12). Furthermore, the apo E polymorphism in a community sample of middleaged adults was associated with memory performance (13).

Several studies have confirmed the association of apo $E$ and the accumulation of amyloid $B$-protein, a characteristic of AD. The early description of this peptide was reported to be associated with the presence of the $\varepsilon 4$ allele in autopsy cases even without signs of dementia (14). In addition, individuals with the $\varepsilon 4$ allele and mutations in the $A P P$ gene have earlier-onset disease compared to those with the $\varepsilon 2$ or $\varepsilon 3$ allele and mutations in APP (15).

In fact, many case-control and post-mortem studies of LOAD patients have shown $\varepsilon 4$ allele frequencies ranging from 17 to $57 \%$ in both sporadic and familial cases (6-
9,16,17). The $A P O E$ genotype, also investigated in other types of dementias, has shown a slight association with VD, Pick's disease and Lewy's body disease but no association with Parkinson's disease or Creutzfeldt-Jakob disease $(10,18)$.

The literature, in general, suggests that there is a relationship between the $\varepsilon 4$ allele and $\mathrm{AD}$. In the present study we analyzed the distribution of $A P O E$ alleles and genotypes in Brazilian patients with clinical signs of LOAD or other types of late-life dementias, mainly VD. We also evaluated the risk for $\mathrm{AD}$ associated with the $\varepsilon 4$ allele.

A total of 165 Caucasian individuals aged 65-82 were studied. Cognitively impaired patients were divided into two groups: a LOAD group (39 men and 29 women) and a group with other late-life dementias (23 men and 16 women) including VD $(\mathrm{N}=35)$, Parkinson's disease $(\mathrm{N}=3)$ and hypothyroidism dementia $(\mathrm{N}=1)$. Control subjects (28 men and 30 women) were members of an elderly healthy group attended in a neurogeriatric unit of a teaching hospital (Faculty of Medicine of São José do Rio Preto, São José do Rio Preto, SP, Brazil). The median ages of the participants at the beginning of this study were $71.5,72.0$ and 70.0 years for patients with $\mathrm{AD}$, other dementias and controls, respectively, without significant difference among them $(\mathrm{P}=0.14)$. A trained physician interviewed each subject or person responsible and obtained informed consent and blood samples. The subjects were diagnosed and classified by historical and physical examination as well as by neuropsychological (NINCDS-ADRDA) criteria and laboratory tests according to standard protocols and guidelines. The study was approved by the Hospital Ethics Committee.

Genomic DNA extraction and $A P O E$ genotyping were conducted according to standard procedures $(19,20)$. Intragroup frequencies of $A P O E \varepsilon 2, \varepsilon 3$ and $\varepsilon 4$ alleles were evaluated by adjusting the chi-square test with equiprobability. Allele and genotype 
frequencies were compared among groups by the test of proportion by normal approximation. The association between the $\varepsilon 4$ allele and $\mathrm{AD}$ and between the $\varepsilon 2$ allele and a protective effect was evaluated by the odds ratio (OR). The level of significance was set at $\alpha=0.05$ for all analyses.

Table 1 shows the distribution of the $A P O E$ alleles and genotypes in patients and controls. $A P O E \varepsilon 2$ was less frequent in $\mathrm{AD}$ than in controls and the $\varepsilon 4$ frequency was significantly higher in $\mathrm{AD}$ than in controls $(\mathrm{P}=0.004)$ but no significant difference was observed for other dementias versus controls $(\mathrm{P}=0.46)$.

Population data have shown a wide variation in the frequency of the $\varepsilon 4$ allele, probably reflecting different methodologies, ethnic diversity, and sample sizes for AD (17 to $57 \%$ ) versus control groups (7 to $16 \%$ ) (6$9,16,17)$. As reported by other investigators, patients also showed a slightly increased frequency of $\varepsilon 4$ in both VD and Lewy's body disease $(10,18)$.

In the present study, although the $\varepsilon 4$ frequency was twice as high in $\mathrm{AD}(0.25)$ compared to controls $(0.12)$, it was still lower than in many other studies. However, it was consistent with the limited Brazilian data ranging from 0.21 to $0.39(7-10,16)$, without a significant difference between patients with presenile or senile dementia (8).

Furthermore, there are the possible confounding effects of age and gender (11). This suggests that each group is a different subset in the general population. Studies of patients with $\mathrm{AD}$ and their relatives can permit a reliable expansion of experiments to measure the prevalence of the $A P O E$ alleles in familial or sporadic $A D$, due to the hereditary nature of the apo E polymorphism. Cação J, De Godoy MR, Pinhel MA, Scudeler D, Fernandez MR, Ruiz V, Romero AMM, Tognola W, Hotta J, Dos Santos JE and Souza DRS (2002, personal communication) showed a significant increase of the $\varepsilon 4$ allele in relatives of $\mathrm{AD}$ patients $(0.24)$ compared with relatives of controls in a Brazilian population (0.04).

The $\varepsilon 3 / \varepsilon 3$ genotype frequencies were higher than other apo E genotype frequencies $(\varepsilon 2 / \varepsilon 2, \varepsilon 2 / \varepsilon 3, \varepsilon 2 / \varepsilon 4, \varepsilon 3 / \varepsilon 4, \varepsilon 4 / \varepsilon 4)$, specifically in controls when compared to $\mathrm{AD}$ in this study (Table 1). Contrasting results were observed for the $\varepsilon 3 / \varepsilon 4$ genotype in $\mathrm{AD}$ $(41 \%)$ and in controls $(16 \% ; \mathrm{P}=0.0008)$. This prevalence is in agreement with other Brazilian series only for controls but not for patients, with the values reported in the literature being 27.3 and $35 \%$ for Caucasian patients versus $17.9(\mathrm{P}=0.234)$ and $16 \%$ for Caucasian controls, respectively $(8,9)$, or black controls (27\%) (9). On the other hand, the $\varepsilon 4 / \varepsilon 4$ genotype was rare mainly in series from the southeast, with values around 5\% (8), including this study, while in a southern Brazilian population this prevalence was $17 \%$, but in a small series (9).

The OR for $\varepsilon 4$ in $\mathrm{AD}$ was $>1$ (Table 2) with a significant effect, again suggesting its influence on the development of the disease. In addition, the estimated $O R$ for $\varepsilon 3 / \varepsilon 4$ confirms the higher risk for $\mathrm{AD}$, as reported in

Table 1. Apolipoprotein E (APOE) allele and genotype frequencies in patients with Alzheimer's disease (AD), other late-onset dementias (OD) and controls (C)

\begin{tabular}{lccc}
\hline APOE allele & \multicolumn{3}{c}{ Number of individuals (absolute frequency) } \\
\cline { 2 - 4 } & $A D(N=68)$ & $O D(N=39)$ & $C(N=58)$ \\
\hline$\varepsilon 2$ & $1(0.01)$ & $3(0.04)$ & $5(0.04)$ \\
$\varepsilon 3$ & $101(0.74)^{*}$ & $62(0.79)$ & $97(0.84)$ \\
$\varepsilon 4$ & $34(0.25)^{*}$ & $13(0.17)$ & $14(0.12)$ \\
\hline APOE genotype & & Number of individuals $(\%)$ & \\
\multicolumn{1}{c}{} \\
\cline { 2 - 4 } & $\mathrm{AD}$ & $\mathrm{OD}$ & $\mathrm{C}$ \\
\hline$\varepsilon 2 \varepsilon 2$ & 0 & 0 & 0 \\
$\varepsilon 2 \varepsilon 3$ & $1(1)$ & $1(3)$ & $4(7)$ \\
$\varepsilon 2 \varepsilon 4$ & 0 & $2(5)$ & $1(2)$ \\
$\varepsilon 3 \varepsilon 3$ & $36(53)^{*}$ & $26(67)$ & $92(72)$ \\
$\varepsilon 3 \varepsilon 4$ & $28(41)^{*}$ & $9(23)$ & $9(16)$ \\
$\varepsilon 4 \varepsilon 4$ & $3(5)$ & $1(3)$ & $2(3)$ \\
Total & $68(100)$ & $39(100)$ & $58(100)$ \\
& &
\end{tabular}

${ }^{*} P<0.05$ compared to $A D$ and controls (test for two independent proportions based on normal approximation) 
other populations (18). However, no association was found with other late-life dementias, represented in this study mainly by $\mathrm{VD}$, although a slight increase in frequencies of the $\varepsilon 4$ allele or $\varepsilon 3 / \varepsilon 4$ genotypes was observed in such cases. As many patients with clinical diagnoses of VD prove to have neuropathologic signs of $\mathrm{AD}$, higher values for $\varepsilon 4$ are expected in this group (6). Similar results were observed for $\varepsilon 2$ and $\varepsilon 3$ in other dementias. Furthermore, the presence of the $\varepsilon 3 / \varepsilon 4$ genotype increased the risk for $\mathrm{AD}$ by a factor of $3.6(95 \% \mathrm{CI}=1.5-8.7)$ using $\varepsilon 3 / \varepsilon 3$ homozygotes as the baseline. However, no significant effect of the $\varepsilon 3 / \varepsilon 4$ genotypes was found in other dementias.

The reduced frequency of genotypes with at least one $\varepsilon 2$ allele in AD substantiates the role of this allele as a protective element. Very low $\varepsilon 2$ allele frequencies were ob-

Table 2. Odds ratio for Alzheimer's disease (AD) and other late-life dementias (OD) according to apolipoprotein E allele frequencies and $\varepsilon 3 / \varepsilon 4$ genotype compared to $\varepsilon 3 / \varepsilon 3$.

\begin{tabular}{lll}
\hline \multirow{2}{*}{ Allele } & \multicolumn{2}{c}{ Odds ratio (95\% confidence interval) } \\
\cline { 2 - 3 } & \multicolumn{1}{c}{$A D(N=68)$} & \multicolumn{1}{c}{$O D(N=39)$} \\
\hline$\varepsilon 2$ & $0.16(0.02-1.43)$ & $0.89(0.20-3.83)$ \\
$\varepsilon 3$ & $0.57(0.30-1.06)$ & $0.76(0.36-1.59)$ \\
$\varepsilon 4$ & $2.43(1.23-4.79)$ & $1.46(0.64-3.30)$ \\
Genotype $\varepsilon 3 / \varepsilon 4$ & $3.63(1.5-8.7)$ & $1.6(0.5-4.5)$
\end{tabular}

served in case-control studies ( 0.03 to 0.08$)$ and even lower ones in $\mathrm{AD}$ (0.01 to 0.08) (7-10,15-18). However, a nonsignificant OR for $\varepsilon 2$ in $A D$ was observed in the present study, suggesting that the $\varepsilon 2$ allele has a very little or no effect in terms of presence or absence of AD, while Bahia et al. (16) observed a significant difference between patients with presenile or senile $\mathrm{AD}(0.05)$ and controls $(0.15 ; \mathrm{P}=0.009)$.

The higher frequency of the $\varepsilon 4$ allele confirmed its role as a risk factor associated with $\mathrm{AD}$, while the $\varepsilon 2$ and $\varepsilon 3$ alleles showed a weak protection, if any, against AD development. Considering the unexpected reduced frequency of the $\varepsilon 4$ allele and the almost complete lack of studies in the Brazilian population, additional analysis with larger and more varied samples is needed to clarify the real contribution of apo E to the development of $\mathrm{AD}$ in this population.

\section{Acknowledgments}

The authors wish to thank Marcia R.F. Ferraz, José Antonio Cordeiro, Márcio Colombo, Flávio A.V. Seixas, Marcos R.H. Estécio, Luis Carlos Mattos, Rosa Kawasaki Oyama, Peter James Harris, Livia C. Burdmann, Carlos Alexandre A. Torres, Mariléia Scartezini and David A. Hewitt for technical assistance, discussions and comments.

\section{References}

1. Bachman DL, Wolf PA, Linn R, Knoefel JE, Cobb J, Belanger A, D'Agostino RB \& White LR (1992). Prevalence of dementia and probable senile dementia of the Alzheimer type in the Framingham study. Neurology, 42: 115-119.

2. Ott A, Breteler MM, van Harskamp F, Claus JJ, van der Cammen TJM, Grobbee DE \& Hofman A (1995). Prevalence of Alzheimer's disease and vascular dementia: association with education. The Rotterdam study. British Medical Journal, 310: 970-973.

3. Herrera Jr E, Caramelli P, Silveira AS \& Nitrini R (2002). Epidemiology survey of dementia in a community-dwelling Brazilian population. Alzheimer Disease and Association Disorders, 16: 103-108.

4. Schellenberg GD, D'Souza I \& Poorkaj P (2000). The genetics of Alzheimer's disease. Current Psychiatry Reports, 2: 158-164.
5. Bertram L, Blacker D, Mullin K, Keeney D, Jones J, Basu S, Yhu S Mclnnis MG, Do RCP, Vekrellis K, Selkoe DJ, Saunders AJ \& Tanzi RE (2000). Evidence for genetic linkage of Alzheimer's disease to chromosome 10q. Science, 290: 2302-2303.

6. Plassman BL \& Breitner JC (1996). Recent advances in the genetics of Alzheimer's disease and vascular dementia with an emphasis on gene-environment interactions. Journal of the American Geriatrics Society, 44: 1242-1250.

7. Larrandaburu M, Chaves MLF \& Hutz MH (1997). Determinação das variantes alélicas da apo E em pacientes com doença de Alzheimer no Rio Grande do Sul. Brazilian Journal of Genetics, 20 (Suppl): 215 (Abstract).

8. Almeida OP \& Shimokomaki CM (1997). Apolipoprotein E4 and 
Alzheimer's disease in São Paulo - Brazil. Arquivos de Neuro-Psiquiatria, 55: 1-7.

9. De Andrade FM, Larrandaburu M, Callegari-Jacques SM, Gastaldo G \& Hutz MH (2000). Association of apolipoprotein E polymorphism with plasma lipids and Alzheimer's disease in a Southern Brazilian population. Brazilian Journal of Medical and Biological Research, 33: 529-537.

10. Mendes Oliveira JR, Lima Filho JL, Shimokomaki CM, Okuma M, Passos-Bueno MR, Zatz M \& Brito-Marques PR (1997). The use of apolipoprotein E genotype for preclinical detection of risk's group for Alzheimer's disease. American Journal of Medical Genetics, 74: 216-217.

11. Hashimoto M, Yasuda M, Tanimukai S, Matsui M, Hirono N, Kazui H \& Mori E (2001). Apolipoprotein E $\varepsilon 4$ and the pattern of regional brain atrophy in Alzheimer's disease. Neurology, 57: 1461-1466.

12. Graves B, Mortimer JA, Bowen JD, McCormick WC, McCurry SM, Schellenberg GD \& Larson EB (2001). Head circumference and incident Alzheimer's disease. Neurology, 57: 1453-1460.

13. Flory JD, Manuck SB, Ferrell RE, Ryan CM \& Muldoon MF (2000). Memory performance and the apolipoprotein $E$ polymorphism in a community sample of middle-aged adults. American Journal of Medical Genetics, 96: 707-711.

14. Morishima-Kawashima M, Oshima N, Ogata H, Yamaguchi H, Yoshi- mura M, Sugihara S \& Ihara Y (2000). Effect of apolipoprotein E allele epsilon-4 on the initial phase of amyloid beta-protein accumulation in the human brain. American Journal of Pathology, 157: 2093-2099.

15. George-Hyslop PH (2000). Piecing together Alzheimer's. Scientific American, 283: 52-59.

16. Bahia VS, Kok F, Marie SK, Caramelli P \& Nitrini R (2001). Polimorfismos dos genes da apolipoproteína $E$ e de sua região promotora e da proteína relacionada ao receptor LDL em pacientes com doença de Alzheimer e controles: resultados preliminares. Arquivos de Neuro-Psiquiatria, 59 (Suppl 3): 27 (Abstract).

17. Weiner MF, Vega G, Risser RC, Honig LS, Cullum CM, Crumpacker $D$ \& Rosenberg RN (1999). Apolipoprotein E epsilon 4, other risk factors, and course of Alzheimer's disease. Biological Psychiatry, 45: 633-638.

18. Relkin NR (1997). The clinical utility of apolipoprotein E genotyping in neurologic practice. American Academy of Neurology 49th Annual Meeting - Age and Dementia/Behavior, 2: 240-263, 240-276.

19. Gustincich S, Manfioletti G, Del Sal G, Schneider C \& Carninci P (1991). A fast method for high-quality genomic DNA extraction from whole human blood. BioTechniques, 11: 298-301.

20. Hixson JP \& Vernier DT (1990). Restriction isotyping of human apolipoprotein $\mathrm{E}$ by gene amplification and cleavage with Hhal. Journal of Lipid Research, 31: 545-548. 